\title{
BITE BY MORAY EEL
}

\section{BARREIROS JP (1), HADDAD JR V $(2,3)$}

(1) Department of Agrarian Sciences and IMAR Açores, University of the Azores, Angra do Heroísmo, Portugal; (2) Department of Dermatology, Botucatu Medical School, São Paulo State University, UNESP, Botucatu, São Paulo State, Brazil; (3) Hospital Vital Brasil, Butantan Institute, São Paulo, São Paulo State, Brazil.

ABSTRACT: Injuries caused by moray eels are not a common problem, but are distributed throughout the globe, affecting mainly fishermen while manipulating hooked or netted fish. On a lesser scale, scuba divers and snorkelers, practicing or not spear fishing, are occasional victims of bites. With more than 185 species distributed among 15 genera, mostly in tropical to temperate shallow water, moray eels easily come into contact with humans and occasional injuries are not uncommon. The current study reports one case of moray eel bite and discusses the circumstances in which the accident happened, as well as wound evolution and therapy.

KEY WORDS: dangerous marine fish, moray eels, bites in humans.

CONFLICTS OF INTEREST: There is no conflict.

\section{CORRESPONDENCE TO:}

VIDAL HADDAD JÚNIOR, Departamento de Dermatologia, Faculdade de Medicina de Botucatu, Caixa Postal 557, 18618-000 Botucatu, SP, Brasil. Phone/fax: +55 14 3882 4922. Email: haddadjr@fmb.unesp.br. 


\section{INTRODUCTION}

Moray eels are widely distributed throughout temperate and tropical seas, and are especially associated with rocky bottoms where caves and crevices are numerous. They form a diverse group with 15 genera and about 185 species presenting an average length of $1.5 \mathrm{~m}$. The largest species, Strophidon sathete, may reach $4 \mathrm{~m}$ long (4). In the Azores archipelago, five species of moray eels have been reported (6), the largest and commonest being Muraena helena (Figure 1).

Although generally regarded as aggressive, there is little documentation on accidents caused by moray eels, except for some reports in the medical literature $(1,5)$. A recent review of the literature was also presented (5). On the basis of clinical evidence, today there are suspicions that toxins in eel saliva could provoke intense and prolonged pain, disproportionate to the bite applied (2).

In this paper we report an unprovoked attack that caused a serious bite on the left hand of a free swimming spear fisherman.

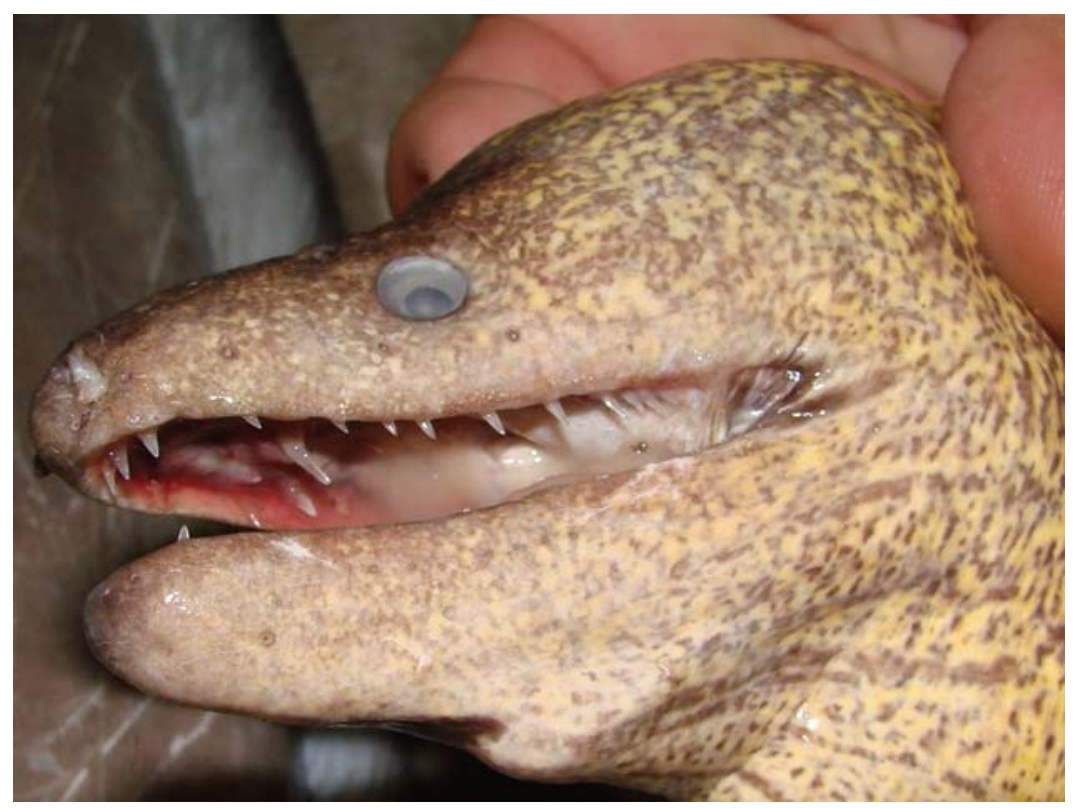

Figure 1. The largest and commonest moray eel in the Azores archipelago is Muraena helena. Note the sharp teeth, capable of to cause lacerations in the victim.

\section{CASE REPORT}

A 42-year-old male, living in Angra do Heroísmo, Azores islands, Portugal. The patient, a fish biology researcher and an experienced diver and underwater spear fisherman for more than 25 years, was free diving (spear fishing) around an islet 
about $9 \mathrm{~km}$ off the south coast of Terceira island. At a depth of 27 meters, when he was placing his left hand on a rocky shelf, it was violently pushed and a moray eel (Muraena helena) was seen shortly afterwards swimming away quickly (approximate total length $1 \mathrm{~m}$ ). At the surface, the wound was evaluated and $3^{\text {rd }}$ and $4^{\text {th }}$ fingers flexor tendons were visible. There was immediate and intense pain that persisted for about 6 hours. Haemorrhaging was controlled and the wound carefully washed. The man went, as rapidly as possible, to the local hospital. There, surgery revealed a deep laceration of skin and muscle over the dorsum of the hand, total laceration of the $3^{\text {rd }}$ finger flexor tendon and a partial tear of the $4^{\text {th }}$ (Figure 2). Tendons were sutured and the wound was closed with seven stitches plus another three on an accessory wound on the basal distal muscle of the hand. Immediate immobilization was followed by anti-inflammatory and antibiotic (1 mg cephalexin/day) prophylaxis. Evolution was favorable and no infection developed. After 12 days mobility was partially recovered although application of manual force was practically impossible (Figure 3). After four months, recovery was considered to be total (Figure 4).

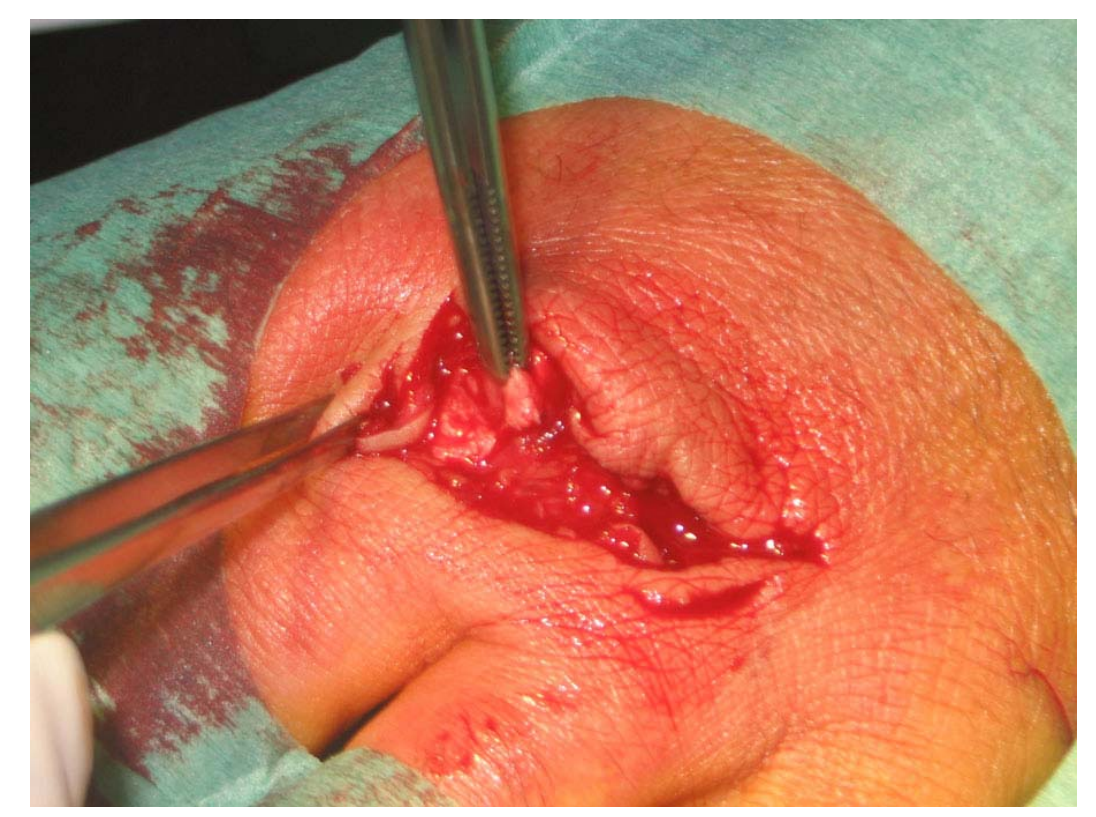

Figure 2. Lesions in the hand of the victim showing laceration of the skin and muscle over the dorsum of the hand, total laceration of the $3^{\text {rd }}$ finger flexor tendon and partial tear of the $4^{\text {th }}$. 


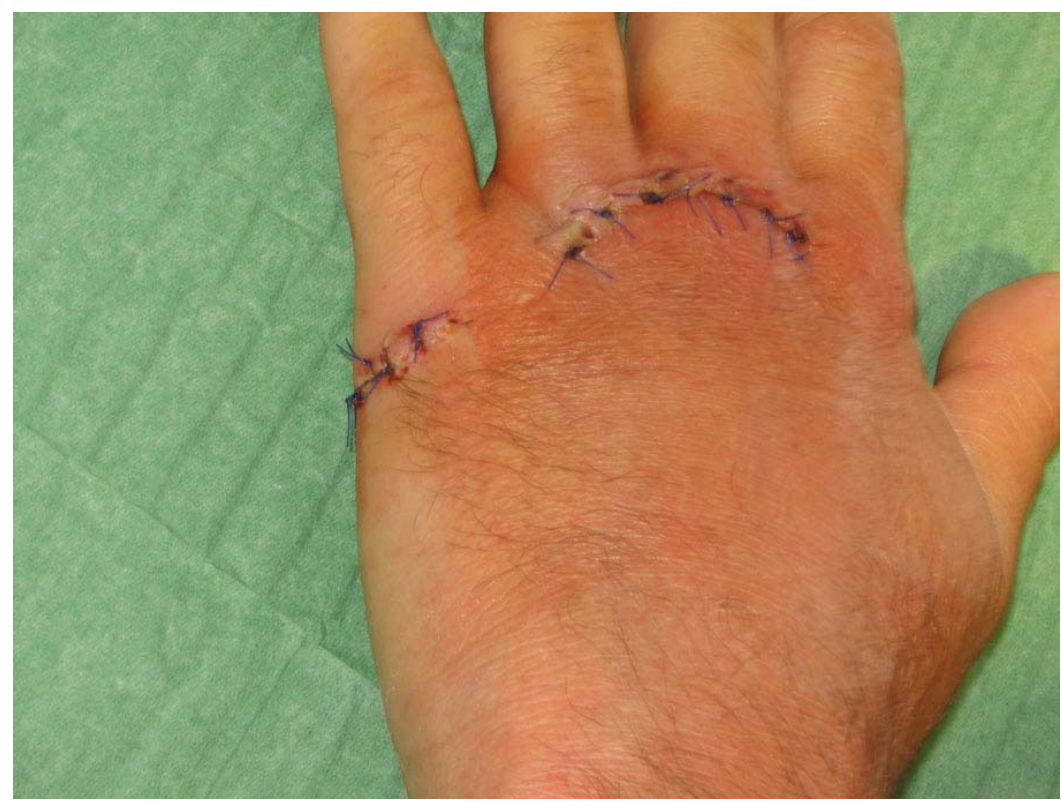

Figure 3. Evolution of the injury after ten days.

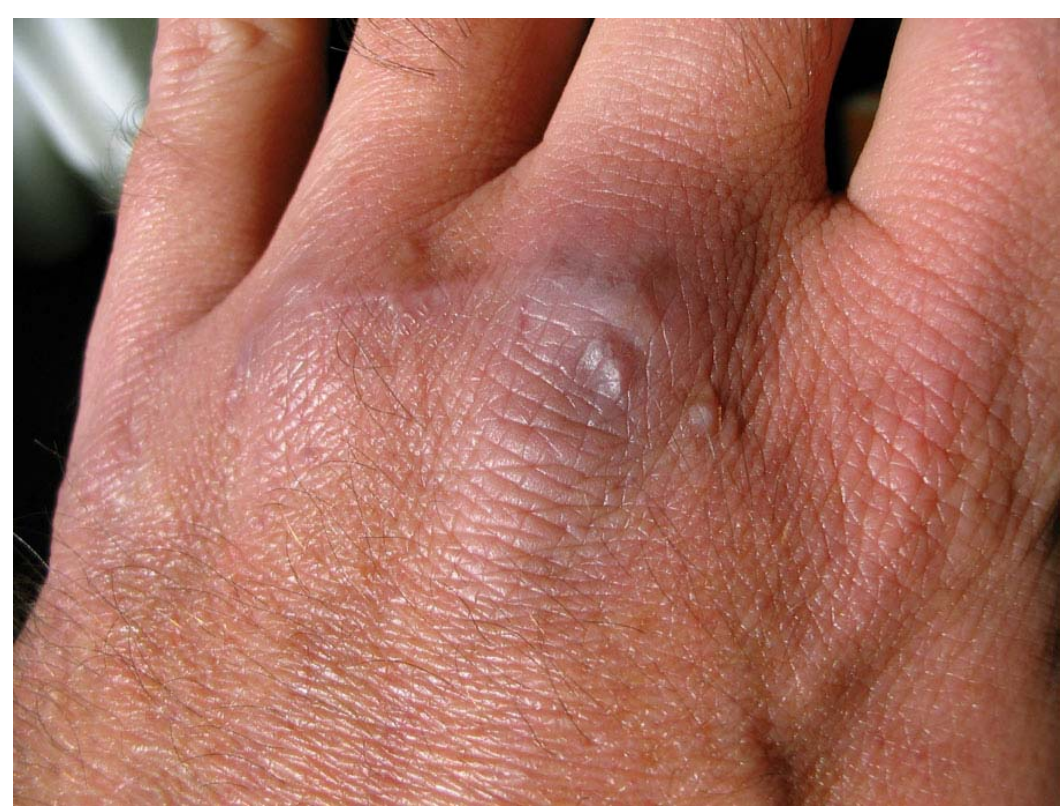

Figure 4. Total recovery of the wound after four months.

\section{DISCUSSION}

According to the four categories of accidents with aquatic animals suggested by some authors $(2,7)$, we agree with the classification of Riordan et al. (5), that moray eels cause injury by biting. Why that should happen is a matter for further study. It is known that bites by moray eels mainly involve divers, spear fishermen and traditional fishermen when handling hooked or netted specimens (2). 
In our case, and because the victim was perfectly aware of the potential development and onset of serious infection, the wound evolved very favorably, especially due to the prehospital phase when the lesion was extensively washed in the sea water, thoroughly cleaned and disinfected with Betadine ${ }^{\circledR}$ (Purdue Products, USA). However, moray eel bites constitute a potential cause of serious bacterial infections (3). There is clinical evidence that toxins exist in its saliva due to the persistence of pain after the bite (2). Injuries provoked by these animals must be monitored until completely healed.

\section{REFERENCES}

1 ERICKSON T., VANDEN HOEK TL., KURITZA A., LEIKEN JB. The emergency management of moray eel bites. Ann. Emerg. Med., 1992, 21, 212-6.

2 HADDAD JR V. Atlas de animais aquáticos perigosos do Brasil: guia médico de identificação e tratamento (Atlas of dangerous aquatic animals of Brazil: a medical guide to identification and treatment). São Paulo: Editora Roca, 2000. 60p.

3 HADDAD JR V. Infecções cutâneas e acidentes por animais traumatizantes e venenosos ocorridos em aquários comerciais e domésticos no Brasil: descrição de 18 casos e revisão sobre o tema. An. Bras. Dermatol., 2004, 79, 157-67.

4 NELSON JS. Fishes of the World. $4^{\text {th }}$ ed. New Jersey: John Wiley \& Sons, Inc, 2006. 601p.

5 RIORDAN C., HUSSAIN M., MCCANN J. Moray eel attack in the tropics: a case report and review of the literature. Wild. Env. Med., 2004, 15, 194-7.

6 SANTOS RS., PORTEIRO FM., BARREIROS JP. Marine fishes of the Azores: annotated checklist and bibliography. Arquipélago: Life and Marine Sciences. Bull. Univ. Azores Suppl. 1, 1997, 244p.

7 STRAUSS MB., ORRIS WL. Injuries to divers by marine animals: a simplified approach to recognition and management. Mil. Med. 1974, 139, 129-130. 